\title{
Effects of Perceived Risk And Bank Reputation Through Online Trust On The Use Of Internet Banking Services
}

\author{
Chatpong Tangmanee \\ Chulalongkorn University, Bangkok, Thailand \\ chatpong@cbs.chula.ac.th \\ Napalai Sritadawut, \\ Chulalongkorn University, Bangkok, Thailand \\ napalai june@yahoo.com
}

\begin{abstract}
Success in online banking services relies on customers' trust. While other studies have examined factors affecting online trust, few have researched on the effects of their perceived risk and their perceived bank reputation on the use of Internet banking services through online trust. The current study attempts to fill this gap. Specifically, we analyzed (1) the extent to which the perceived risk and the bank reputation affect the use of Internet banking services through online trust, and (2) the extent to which the bank reputation affects the perceived risk.

416 samples of the Internet banking users returned their questionnaires. The model was assessed and verified using the confirmatory factor analysis (CFA) and the structural equation modeling (SEM). The analysis confirmed the significant effects of the perceived risk and the bank reputation on the use of the services through online trust, yet, the effect of the bank reputation on the perceived risk was not significant. In addition to extending theoretical insights into the Internet banking users' online trust is significantly explained by both of the perceived risk and the bank reputation.
\end{abstract}

Keywords: Online Trust, Perceived Risk, Bank Reputation, Internet Banking Services

\section{PROBLEM STATEMENT}

Banks worldwide have promoted Internet banking services. It is mainly because they have helped the banks effectively to control service costs. In addition, online services offer customers a convenient channel to complete basic banking transactions. According to Juniper research [1], the number Internet banking customers is estimated to be roughly two billion in 2020. The largest proportion of bank customers in Europe (45\%) still use both in-branch and online channels, however, the latter is increasingly more popular than the former [2]. Such a high increase has confirmed the great acceptance of Internet banking services.

Online trust has gained remarkable research attention. [3-6] Compiled from various literature, it is defined in the current study as bank customers' willingness to be 
vulnerable to the actions of the other party (e.g., the bank's online services) based on the expectation of what the bank can deliver. Trust typically deals with relationships between at least two parties. In the context of Internet banking, it could be customers' trust towards the bank's website or vice versa. The banks however appear to have full control of their virtual services. Such control includes the design of the bank website, the technical security provided for the customers or the back-end operation. As a result, the customer's trust has been the prime issue of research included in this current study.

Previous research on online trust can be classified into two major categories. The first one looks at trust as a process while the second one considers it as a unified concept. As a process, researchers have made an effort to understand how online trust is developed. McKnight, Choudhury \& Kacmar [7] validated the process through which online trust is transformed into behavior. Specific to Internet banking, the model claims that bank customers are disposed to trust as they visit the bank websites. In addition to the disposition, their perception of the institution environment (e.g., the bank's structural characteristics including security seals, or the trust that is transformed from the offline context related to the bank) will lead them to develop trusting beliefs. [8] According to psychology research, the trusting beliefs together with the disposition to trust and the institution-based trust will drive an intent to engage in certain trust-related behavior, such as completing banking transactions. McKnight, et al. [7] also confirmed three common components of trusting beliefs: competence, benevolence, and integrity. In fact, bank customers consider content provided on the websites and subsequently assess the extent to which they trust the bank and its website. [9] Such content including a disclaimer or feedback on services may be so compelling that viewers are willing (or unwilling) to engage in online banking transactions. [10] Trust is therefore the cognitive process.

As a unified concept, trust is examined in relation to other variables. Few studies have addressed the antecedents and the consequences of online trust. [8] Among many antecedents of online trust, we are interested in the risk perceived by bank customers. Given the sensitive issues of financial transactions, banks must ensure that their websites where transactions are initiated are equipped with the details that can eradicate all fear the customers may have while completing the transactions. A slight shed of perceived uncertainty may drive them away from this online channel. [11,12] As a result, perceived risk inevitably is related to online trust in the context of Internet banking.

In this study, the perceived risk is defined as a customer's perception of uncertainty in the transaction through websites or in the outcome of the transaction. Such perception may come mainly from fear to do an online banking transaction. A fair amount of previous work has addressed customer's perceived risk but different terms are often used, such as perceived insecurity or perceived uncertainty. $[5,13]$ While the other terms are acceptable, they often connote technical aspects of an electronic commerce system. However, our study attempts to address such awareness from the customer's perspective. According to Urban, et al's [5] remark, if customers are empowered by content on websites or by careful store layout design, they are likely to trust and engage in an online banking transaction. Examining what contributed to online trust, Yao and Li [14] reported a negative correlation between customers' perception of risk while doing online transaction and their trust in electronic commerce. Salem et al [15] addressed the customers' perceived risk and online trust but they did not test the 
connection between these two variables. According to Eroglu et al.'s [9] model, which is based on the Stimulus-Organism-Response (S-O-R) framework, trust can be viewed as the cognitive aspect of the Organism. Online trust is in the customer's mind governing an online banking transaction through a website. [9] Later, Eroglu, Machleit \& Davis [16] empirically confirmed the validity of their model. As a result, our first hypothesis will be as follows:

H1: customers' perceived risk is negatively related to their online trust.

The customers' online trust towards Internet banking websites depends not only on their perceived risk but also their perception of the bank's reputation. It helps customers to trust the bank's web-based services. [14,17] Bank reputation could be judged by a high interest rate, the rewards earned from local and international agencies, the friendly services over the counter in the branch or favorable feedback on various platforms. Those with a high reputation will be more likely to earn high trust in the online channel than those with a poor reputation.

Hence, bank reputation is defined in the current study as customers' positive perception of the bank as a result of their exposure to the details on the bank's website or their prior experience with the bank (e.g., visitors to the bank's website may perceive bank reputation differently from loyal customers to the bank). In a general online context, Kotha, Rajgoppal \& Rindova [18] contended that people prefer to do more transactions from reputable websites than from unfamiliar online locations. When customers browse websites, their decisions to do a transaction are based on their prior experience with the physical stores or on contents including all comments and feedback on the websites. Should the information lead website visitors to feel secure, they are likely to engage in a transaction. [19] According to Kim and Lennon [4], a bank may earn its reputation from two sets of information cues. One is the extrinsic cues referred to as the attributes related directly to the bank. Such cues include the prior experience at the bank counter or the exposure to bank information through various channels. The other is the intrinsic cues referred to as the attributes related directly to the website. Such cues include the functionality of the bank website in its visually appealing content on the website. The bank's reputation in the current study is thus a function of the two information cues. [4]

Heijden, Verhagen, \& Creemers [20] remarked that little attention had been given to examine the connection between bank reputation and trust. Most of previous literature had addressed whether technical attributes could enhance online trust. Yao and Li [14] used the structural equation modeling technique to confirm the positive relationship between reputation and trust on one Chinese website. Also, Yoon [13] discovered the significant correlation between trust and reputation (or in Yoon's term is the site properties). Kim and Lennon [7] verified the positive link between website reputation and perceived risk. Among other variables, Kesharwani and Bisht [21] examined perceived risk, online trust, Internet banking adoption and bank reputation using the technology acceptance model (TAM) and confirmed the direct correlation between the perceived risk and the bank reputation and that between the perceived risk and online trust. Furthermore, the Stimulus-Organism-Response (S-O-R) framework treats the bank reputation and online trust as its stimulus and organism, respectively. As a result, Hypotheses 2 and 3 will be stated as follows:

H2: customers' perceived bank reputation is positively related to their online trust, and 
H3: customers' perceived bank reputation is negatively related to their perceived risk.

Readers should note that the bank reputation and perhaps the risk together with the online trust are all customer's perception. They are inevitably evolving. As a result, the measurement of these three constructs are formative. It may impose slight concern on generalizability of the study's findings.

The consequence of online trust in the current study's Internet banking setting is the use of Internet banking services measured by the number of transactions the customers completed using the Internet channel. The completion can be through the customer's desktops, notebooks, tablets, or their smart mobiles. The banking transactions in the current study include statement and balance inquiries, check and credit card transactions, and money transfer and bill payment. These are instances of trust-related behavior [7,13] or benefits of online banking. [22] It is conceptually similar to the fifth element in Bitner's [23] Servicescapes and to the response's component of the Stimulus-Organism-Response (S-O-R) framework. [9] In their attempt to verify online trust model, McKnight, et al. [7] proposed the direct link between the trusting belief and the trust-related behavior. Despite much research on electronic commerce and Internet banking services, empirical studies confirming the link between online trust and the number of banking transactions are rare. [21,24,25] Nonetheless, Salem et al. [15] discovered a significant link between online trust and the use of online banking among Palestinian customers. Many of the studies examined only the connections between online trust and the intention to engage in online transactions. [25] In the general context of electronic commerce, online trust was found to have a significant yet indirect effect on purchase intention. [4,26] These two studies confirmed the effect mediated through customers' perceived risk. The indirect effect of trust on purchase intention was also evident in Heijdon, et al [27] and Kwok, Wong, \& Lau [28]. By virtue of trust, we assume that the higher the trust, the more frequency the online banking transactions completed. Consequently, Hypothesis 4 will be stated as the following. Figure 1 shows the study's conceptual model with the four proposed hypotheses.

H4: customers' online trust is positively related to the number of online banking transactions.

In conclusion, the current study proposed and tested the model in which online trust is a variable mediating the effect of perceived risk and bank reputation to the use of Internet services (see Figure 1). Specifically, we attempted to test (1) the effect of perceived risk and bank reputation on trust, (2) the effect of bank reputation on perceived risk, and (3) the effect of trust on the use of Internet banking services. 


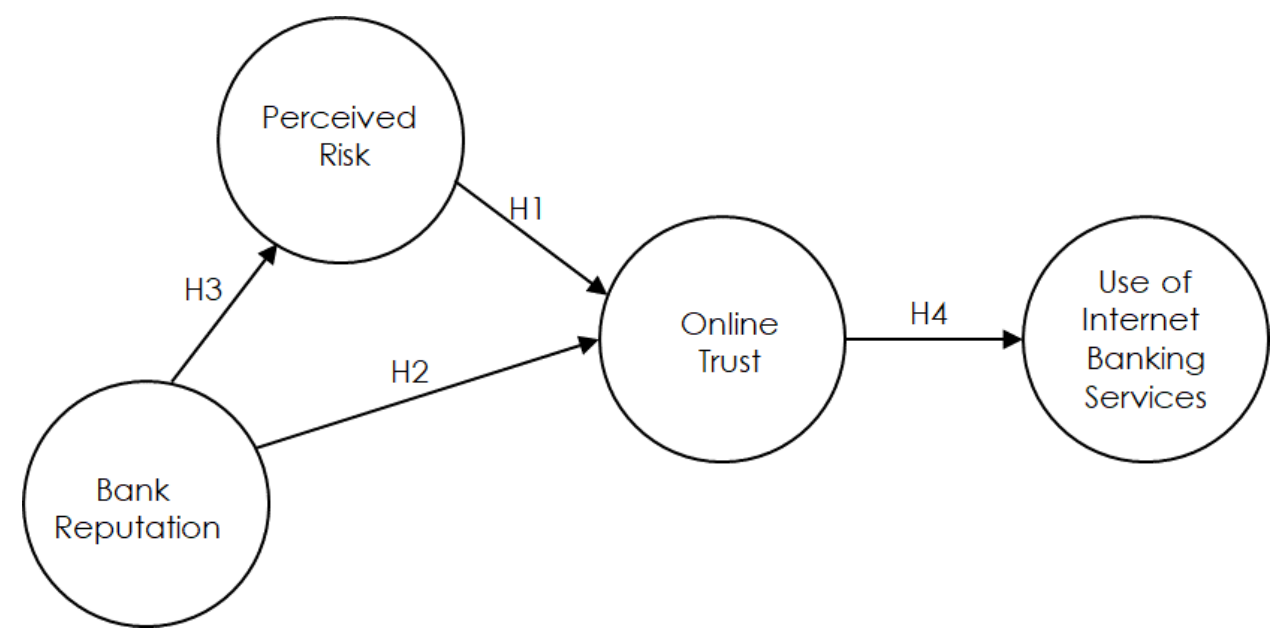

Figure 1. Conceptual framework consisting of four constructs and proposed hypotheses

\section{METHODOLOGY}

Given the sizable body of knowledge on online trust together with its antecedents and consequences, our approach can be quantitative using questionnaires as the survey instrument. Based on the theoretical framework, we adopted questionnaire scales of acceptable quality in previous literature. This allows us to use such advanced statistical treatments as the structured equation modelling (SEM) and the confirmatory factor analysis (CFA).

\subsection{Questionnaire Development}

The survey questionnaire consisted of five major sections. Section 1 asked five questions to measure the subjects' perceived risk. The scales were adjusted from Mwesigwa. [29] In Section 2 consisted of five questions asking the frequency with which subjects had completed banking transactions using the Internet banking services. The frequency ranges from less than once a month, at most three times a month, to 4-5 times a month and greater than five times a month. Six questions in Section 3 and five questions in Section 4 were asked about the subjects' perceived bank reputation and their online trust, respectively. The six were adjusted from Man [30] and Corritore, Marble, Wiedenbeck, Krancher, \& Chandran [31] while the five were borrowed from Mwesigwa [29] and Sunm, et al [32]. The final section asks about the subjects' demographics including what are the banks the subject routinely visited, or which channels they used to access the online services.

Since the subjects are Thai, we translated all items into Thai and had them checked by two faculty members in the language institute to ensure the translation quality. We subsequently pretested them with three members at Chulalongkorn Business School and five users on the Internet banking services in order to assess the face validity. We made a few changes based on comments from the pretest participants.

\subsection{Sampling and Data Collection}

We used a web-based survey because members of the target population are those who have been Internet banking users for at least one year. As a result, we had a few screening questions at the beginning of the survey to recruit only qualified subjects. To 
draft and manage the online questionnaire, we decided to use the Google Doc service with a convenient sampling style.

According to Dillman [33], we needed at least 400 samples for the 5\% acceptable error rate. The call for research participants was placed through multi channels including personal email contacts and various online discussion boards on electronic commerce topics. Included in the call for research involvement was the explanation through which the sample's participation was assured (1) the anonymity and confidentiality and (2) no right or wrong answer. Such explanation followed the recommendations of Podsakoff, MacKenzie, Lee, \& Podsakoff [34] and Chang, Witteloostujin, \& Eden [35] to minimize the problem of common method variance (CMV).

We were finally able to have the 416 qualified subjects within the ten-week data collection. Of the 416 participants, $61 \%$ were men, 55\% (the largest proportion) were $31-40$ years of age, and $63 \%$ were staff working in private companies (see Table 1 for the detail). 5 in 10 had 1-3 years of experience using Internet banking services. About $68 \%$ used it at most three times a month. Regarding the usage channels, 50\% used their notebooks or desktops and the rest used their smart phones or tablets.

\subsection{Analysis}

Relying on the two-approach recommended by Anderson and Gerbing [36], we first confirmed the measurement using confirmatory factor analysis (CFA). Structural equation modeling (SEM) was then estimated for hypothesis testing. In addition to the two-step approach, descriptive statistics were provided.

Table 1. Demographic Profile of the Respondents $(n=416)$

\begin{tabular}{|c|c|}
\hline \multicolumn{1}{|c|}{ Demographic Variables } & $\mathrm{N}(\%)$ \\
\hline Gender & \\
\hline Male & $254(61)$ \\
\hline Age & $162(39)$ \\
\hline$<20$ yrs & $8(2)$ \\
\hline $21-30$ & $125(30)$ \\
\hline $31-40$ & $227(55)$ \\
\hline$>40$ yrs & $56(13)$ \\
\hline Profession & \\
\hline Private companies & $261(63)$ \\
\hline Self-employed & $66(16)$ \\
\hline Government agencies & $54(12)$ \\
\hline Students & $24(6)$ \\
\hline Others & $11(3)$ \\
\hline$<1$ yr & \\
\hline $1-3$ & $48(11)$ \\
\hline $4-5$ & $181(44)$ \\
\hline$>5$ yrs & $88(21)$ \\
\hline Years of Internet experice & $99(24)$ \\
\hline Frequency (per month) of using Internet banking servies & \\
\hline$<1$ yr & $144(35)$ \\
\hline $1-3$ & $128(31)$ \\
\hline $4-5$ & $65(16)$ \\
\hline
\end{tabular}


Table 1. Demographic Profile of the Respondents $(n=416)$

\begin{tabular}{|c|c|}
\hline$>5$ yrs & $79(18)$ \\
\hline Channels to use Internet banking services & \\
\hline Notebooks or PCs & $210(50)$ \\
\hline Mobiles, Tablets or Others & $206(50)$ \\
\hline
\end{tabular}

Both the measurement model and the structural model were assessed using the maximum likelihood method [37] in AMOS (version 22). To evaluate the fit of models, the comparative fit index (CFI), the goodness of fit index (GFI), the adjusted goodness of fit index (AGFI), the normed fit index (NFI) and root mean square error of approximation (RMSEA) were assessed in addition to the chi-square test. In general, model fit is considered to be adequate if GFI, NFI and CFI are larger than 0.9, AGFI is larger than 0.8 and RMSEA is smaller than 0.08 . [36,38]

\section{RESULTS}

The measurement model yielded the ratio of the chi-square to the degrees of freedom $(\chi 2 / \mathrm{df})$ is 1.884 , which falls within the suggested value of 5 or below. [36] In addition, all indices appear to confirm the measurement model (CFI $=0.955$, GFI $=0.910$, AGFI $=0.876$, NFI $=0.909$ and RMSEA=0.054). Hence, there was an acceptable fit between the model and the observed data.

Furthermore, each construct was evaluated separately by examining the indicator loading for statistical significance and assessing the construct's reliability and variance extracted. [36] As shown in Table 2, the Cronbach's alpha for each of the four constructs is higher than 0.7 , the threshold of which is considered acceptable. [39] Also, the composite reliability values for all of the four constructs are larger than 0.7, confirming the construct reliability.

To establish the measurement's discriminant reliability, we adopted the average variance extracted technique. As reported in Table 3, the values of the average variance extracted for all, but not the bank reputation, constructs are higher than 0.5, the threshold of which is considered acceptable. [40] This could imply that the six questionnaire items measuring the bank reputation construct may not be able sufficiently to capture the variation since it could explain roughly $44.0 \%$. As a result, we followed recommendations in Fornell and Larcker [40] and calculated the squared root of the average variance extracted of the bank reputation. It is 0.663 , which is still larger than the correlation coefficients of this variable and the other three constructs (i.e., 0.024, 0.500, and 0.221). We thus confirm the discriminant validity of our measurement. However, an inspection of all constructs' AVE and the squared multiple correlation in Table 3 indicates the slight problem of the measurement validity. This problem may be a result of the formative measurement of the bank reputation. This may nevertheless entail certain limitations of the current study's findings.

After the measurements mostly appear valid and reliable, descriptive statistics of the four constructs were computed and shown in Table 4. An examination of skewness and kurtosis in Table 4 validated that all four constructs are normally distributed since absolute values of the two statistics are all less than one. [41] 
Table 2. Measurement Model Fit Indices for Reliability

\begin{tabular}{|l|c|c|}
\hline \multicolumn{1}{|c|}{ Constructs } & Cronbach's alpha & $\begin{array}{c}\text { Composite } \\
\text { reliability }\end{array}$ \\
\hline Perceived risk & 0.840 & 0.843 \\
\hline Bank Reputation & 0.823 & 0.821 \\
\hline Online Trust & 0.863 & 0.868 \\
\hline Use of Internet Banking Services & 0.785 & 0.876 \\
\hline
\end{tabular}

Note: Criteria: Cronbach's alpha $>0.70$ and composite reliability $>0.50$

Table 3. Correlation Matrix and Average Variance Extracted (AVE)

\begin{tabular}{|c|c|c|c|c|}
\hline & $\begin{array}{l}\text { Perceived } \\
\text { risk }\end{array}$ & $\begin{array}{l}\text { Bank } \\
\text { reputation }\end{array}$ & $\begin{array}{l}\text { Online } \\
\text { trust }\end{array}$ & $\begin{array}{l}\text { Use of Internet } \\
\text { Banking Services }\end{array}$ \\
\hline Perceived risk & 0.538 & & & \\
\hline Bank reputation & $\begin{array}{c}0.024 \\
(0.001)\end{array}$ & 0.440 & & \\
\hline Online Trust & $\begin{array}{l}-0.344^{* *} \\
(0.118)\end{array}$ & $\begin{array}{l}0.500^{* *} \\
(0.250)\end{array}$ & 0.526 & \\
\hline $\begin{array}{l}\text { Use of Internet } \\
\text { Banking Services }\end{array}$ & $\begin{array}{l}-0.168^{* *} \\
(0.150)\end{array}$ & $\begin{array}{l}0.221^{* *} \\
(0.049)\end{array}$ & $\begin{array}{l}0.312^{* *} \\
(0.097)\end{array}$ & 0.574 \\
\hline
\end{tabular}

Note: Correlation coefficients in each cell and average variance extracted (AVE) on diagonal, ** $\mathrm{P}$-value $<.01$, and in parenthesis is the squared correlation.

To assess the model structure and to test all hypotheses, AMOS (version 22) was used with the maximum likelihood method. Given the multiple and interrelated dependence relationships among the constructs, the structural equation modeling technique is appropriate. The overall fit of the model is acceptable. The ratio of chi-square to the degrees of freedom $(\chi 2 / \mathrm{df})$ is 2.061 , indicating a good fit. The other indices confirm the acceptable fit of the model (CFI $=0.946, \mathrm{GFI}=0.919, \mathrm{AGFI}=0.898, \mathrm{NFI}=0.902$, RMSEA $=0.051$ with the $p$-value of 0.439 , and HOELTER $.05=238$ ).

Table 4. Descriptive statistics

\begin{tabular}{|l|c|c|c|c|}
\hline & $\begin{array}{c}\text { Perceived } \\
\text { risk }\end{array}$ & $\begin{array}{c}\text { Bank } \\
\text { reputation }\end{array}$ & $\begin{array}{c}\text { Online } \\
\text { Trust }\end{array}$ & $\begin{array}{c}\text { Use of Internet } \\
\text { Banking } \\
\text { Services }\end{array}$ \\
\hline Mean $^{+}$ & 3.09 & 4.02 & 3.73 & 2.74 \\
\hline Standard deviation & 0.905 & 0.613 & 0.592 & 0.887 \\
\hline Skewness & 0.013 & -0.486 & -0.070 & 0.417 \\
\hline Kurtosis & -0.361 & 0.969 & 0.309 & -0.337 \\
\hline
\end{tabular}

Note: +1 is the least and 5 is the highest agreement

The result shown in Figure 2 supported H1, H2 and H4. Yet, H3 was not supported. Customers perceived risk and their perceived reputation of the bank contributed significantly to their trust toward the website for online banking. While the contribution 
of the latter is positive, that of the former is negative. The findings support the logic through which (1) the higher the risk perceived, the less the trust, and (2) the higher the bank reputation, the larger the trust. It implies that $\mathrm{H} 1$ and $\mathrm{H} 2$ are supported. Moreover, the customers' trust significantly accounted for a certain portion of the use of Internet banking services. The finding has supported H4. However, the positive link between the bank reputation and the perceived risk (H3) was not confirmed. Further discussion will be in the next section.

\section{CONCLUSION AND DISCUSSION}

The findings provide empirical support for the conceptual framework in Figure 1 and for the hypotheses regarding the correlation among the four constructs. The analytic results demonstrate that customers' perceived risk and their view of the bank reputation significantly affect their online trust, and in turn, their purchase intention toward online transaction. Yet, the proposed positive effect of the bank reputation on the perceived risk was not confirmed. The discussion is below.

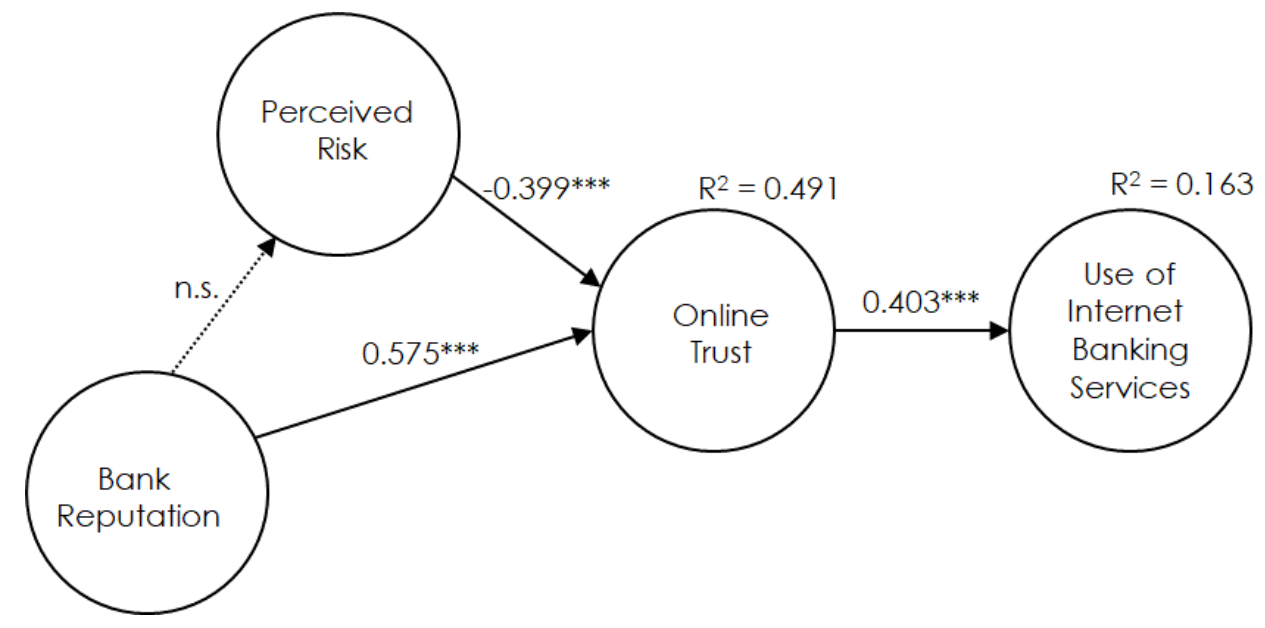

Figure 2. Summary of results in the hypothesized structural (standardized) model. Note: Significant at $\mathrm{p}<0.05, \chi 2=377.130, \mathrm{df}=183$ ( $\mathrm{p}$-value $=0.000$ ), $\chi 2 / \mathrm{df}=2.061$, $\mathrm{CFI}=0.946, \mathrm{GFI}=0.919, \mathrm{AGFI}=0.898, \mathrm{NFI}=0.902, \mathrm{RMSEA}=0.051$, PCLOSE $=0.439$, and HOELTER $.05=238$.

First, the study shows that online trust is attributable to both customer's perceived risk and their perceived bank reputation. The contribution is notable for the R2 of 0.491 . Furthermore, the trust has slightly but significantly contributed to customers' use of Internet banking services since the R2 is 0.163 . Such findings are empirical evidence and consistent with the results of previous work. [4,5] The negative coefficient between the perceived risk of online transaction and the trust toward an online banking website implies that the customers who perceived the high risk associated with the online banking transaction may develop less trust toward the website, as compared to those who perceive less risk. Such finding is in line with the main body of previous research. $[11,26]$ Mou and Cohen [42] confirmed the negative link between the risk perceived by visitors to one healthcare website and their trust toward the content on the website. 11 out of 85 electronic commerce academic papers reviewed by Akar and Nasir [43] confirmed the negative correlation between the perceived risk and the online trust. The negative link is also evident in developing countries. [21,44] 
Based on the positive coefficient between the perceived bank reputation and the online trust, if banks earn a large reputation, they could as well earn a high amount of trust in the online platform. Such finding is consistent to what has been reported in previous literature. Should customers establish a favorable attitude towards banks (the favor could be from the bank's well established brand or their actual experience at the counter in the bank hall), they would likely develop the trust towards the online banking services (Koskosas, 2008). This may be an instance of what McKnight et al [7] called an institution-based trust. In a common electronic commerce environment, after customers are exposed to given detail from certain sources, they often evaluate whether or not the detail is valuable or useful. Once they are aware of its value, they would develop trusting belief toward the source or the website. [45] Planning a trip to the location with which people have no experience, they probably rely on the reviews or ratings given by previous visitors on travelling-related websites. Spacks and Browning [46] discovered the significant influence of customers' rating on hotels and their online review of the hotels on their perception of trust and their willingness to hotel-booking. Ozturen [47] also discovered similar findings on the Tripadvisor website.

Second, the absolute values of the standardized coefficients shown in Figure 2 suggest that the effect of the bank reputation (i.e., its value is 0.575 ) on the online trust is higher than that of the perceived risk (i.e., its value is 0.399). It further implies that customers' online trust appears to be more sensitive if they perceive a high reputation of the bank than if they perceive a small amount of risk. In the online retail context; however, Tangmanee and Rawsena [48] confirmed that the perceived risk had more significant impact on viewers' trust than reputation of the website. As a result, the effect of the perceived risk and that of the store reputation appear to have different impact on viewers' online trust. It depends upon the type of the website. Should the website is financial, the viewers' online trust is more sensitive to the institute's reputation than to the perceived risk. Nevertheless, the sensitivity reverses if the website offer retail transactions. [48] This is perhaps our unique contribution to the fields of electronic commerce or Internet banking.

Third, the positive contribution of online trust on the use of online banking services found in the current study is in harmony with previous literature. In a general setting of electronic commerce, $95 \%$ of academic articles examining the link between online trust and the purchase intention in the web-based context confirmed the positive correlation between them and the link discovered in the remaining articles was not statistically significant. [40] In a specific setting of the Internet banking, Ong and Lin [11] confirmed the positive link between the online trust and the Internet banking adoption among customers of Taiwanese banks. Also, in Korea, Kim et al [49] verified the direct effect of the online trust on the Internet banking usage and its mediation on the usage through the perceived risk. Similar findings were found in Uganda [24] and in Thailand. [25] It is thus reasonable to conclude that the findings in the current study will definitely add to a sizeable body of literature confirming the positive impact of online trust on the adoption of the Internet banking. In addition, our unique accumulation to the literature is that customer's perceived reputation of the bank is more significant to their trust than their perceived risk.

Finally, the trivial link between the bank reputation and the perceived risk warrants further discussion. According to the Stimulus-Organism-Response (S-O-R) framework, we postulated that customers' perceived bank reputation seems to represent the stimulus component of the framework and their perceived risk toward online banking transaction 
is the organism. [9,17,23] Initially, we attempted to test the effect of the bank reputation on the perceived risk. Yet, our analysis failed to verify it. There are two possible explanations. First, the applicability of the Stimulus-Organism-Response (S-O-R) framework to the current study's online context is in question. While the framework has been empirically validated in previous research, [16,50] the contexts in the past literature are all online. For instance, an exploration into online gamblers' experience was substantial using the S-O-R framework. [50] Nevertheless, the bank reputation in the current study was referred to as all reputation the bank has earned as a result of customers' exposure not only to the online detail (e.g., the customers realized the content included in the bank website) but also the offline context (e.g., a television broadcasted the bank has won the president's choice award). This may account for the trivial link. Second, our interpretation of the S-O-R component may be inaccurate. We should have classified the perceived risk and the perceived bank reputation as the framework's stimulus component. This is because these two constructs could be drivers stimulating the online trust. Either way, future work on such classification is needed for the empirical verification.

The study's findings have extended theoretical insight into effects of customers' perceived risk and their perceived bank reputation on the use of Internet banking services through online trust. Our conceptual contribution is the empirical validation of the framework in Figure 1 using the structural equation modeling technique.

Also, our discovery has practical utility. First, practitioners must be attentive to both antecedents of online trust. Since they accounted for the large portion of trust, bankers may look for a design guideline on how to enhance the reputation of the bank or to reduce any risk the customers may have regarding the online banking transaction. Second, the effect of the perceived bank reputation on the trust is more significant than that of the perceived risk. If budget is the issue, bankers may thus choose to execute the plan that could boost a customer's perception of the bank reputation. Once it is raised, the customer is likely to establish the high amount of trust, which subsequently leads to high possibility of online shopping.

Similar to other research projects, the current study has three limitations. First, one of the main constructs (i.e., the perceived bank reputation) was marginally reliable while the others are of acceptable standard. This may have to do with the bank reputation's formative assessment. Despite this shortcoming, the entire model is still of good quality based on statistics figures. Should the measurement of the perceived bank reputation have been revised in the next research project, the new finding may have been much more interesting. Second, the current study has dealt with the rapid evolution of the online platform. What happens in the context of the present research may change rapidly. For instance, the Internet banking services in subsequent studies may need clear and distinctive definitions between the mobile banking applications and the services on the desktops or the notebooks since users may have different perceptions toward them. Finally, although we included certain explanation detailing how we assured the survey subjects about the anonymity and confidentiality of their participation as a means to cope with the common method bias, we had to admit the slight possibility of the concern. It is because our questionnaire was self-reported with a similar format of questionnaire scales measuring all major constructs. The application of the finding must therefore be used with caution.

\section{CITATIONS}


[1] Juniper research (2016). Mobile Banking Users to Reach 2 Billion by 2020[Online].Available:www.juniperresearch.com/press/press-releases/mobilebanking-users-to-reach-2-billion-by-2020.

[2] Statista (2019). Which type of bank are you currently a customer of? [Online]. Available:https://www.statista.com/statistics/745590/bank-customersdistribution-by-bank-type-in-italy .

[3] Corbitt, B. J., Thanasankit, T., Yi, H "Trust and e-commerce: A study of consumer perceptions." Electronic Commerce Research and Applications, Vol 2, pp. 203215, 2003.

[4] Kim, J., Lennon, S. "Effects of reputation and website quality on online consumers' emotion, perceived risk and purchase intention based on the stimulusorganization-response model." Journal of Research in Interactive Marketing, Vol. 7, No. 1, pp. 33-56. 2013.

[5] Urban, G. L., Amyx, C, Lorenzon, A. "Online trust: State of the art, new frontiers and research potential." Journal of Interactive Marketing, Vol. 23, pp. 179-190. 2009.

[6] Karmawan, K., Suhaidar, S. "Effect of online systems quality, banking service product quality and customer trust on the success of brisyari'ah e-banking information system." integrated journal of business and economics[Online]. Vol. 3,No.1,pp.116-127.Available:https://mpra.ub.uniuenchen.de/91578/1/MPRA_paper_91578.pdf

[7] McKnight, D. H., Choudhury, V., Kacmar, C. "Developing and validating trust measures for e-commerce: An integrative typology." Information Systems Research, Vol. 13, No. 3, pp. 334-359. 2002.

[8] Shankar, V., Urban, G., Sultan, F. "Online trust: A stakeholder perspective, concepts, implications and future directions." Journal of Strategic Information Systems, Vol. 11, pp. 325-344. 2002.

[9] Eroglu, S. A., Machleit, K. A., Davis, L. M. "Atmospheric qualities of online retailing: A conceptual model and implications", Journal of Business Research, Vol. 54, pp. 177-184. 2001.

[10] Hunter, R., Mukerji, B. "The role of atmospherics in influencing consumer behavior in online environment", International Journal of Business and Social Science, Vol. 2, No. 9, pp. 118-125. 2011.

[11] Ong, Ch.-Sh., Lin, Y. L. 'Security, risk, and trust in individuals' Internet banking adoption: An integrated model", International Journal of Electronic Commerce Studies, Vol. 6, No. 2, pp. 343-356. 2015.

[12] Koskosas, L. V. "Trust and risk communication in setting Internet banking security goals." Risk Management, Vol. 10, No. 1, pp. 56-75. 2008.

[13] Yoon, S.-J. "The antecedents and consequences of trust in online-purchase decisions." Journal of Interactive Marketing, Vol. 16, No. 2, pp. 48-63. 2002.

[14] Yao, G., Li. Q. "The Impact of Familiarity and Reputation on Consumer Trust in E-Commerce." Proceedings of the 4th International Conference on Wireless Communications, Networking and Mobile Computing, Dalian, China, 2008. pp. $1-5$.

[15] Salem, M. Z., Baidoun, S., Walsh, G. "Factors affecting Palestinian customers' use of online banking services." International Journal of Bank Marketing, Vol. 7, No. 2, pp. 426-451. 2019

[16] Eroglu, S. A., Machleit, K. A., Davis, L. M. "Empirical testing of a model of online store atmospherics and shopper responses." Psychology \& Marketing, Vol. 20, No. 2, pp. 139-150. 2003. 
[17] Einwiller, S. "When reputation engenders trust: An empirical investigation in business-to-consumer electronic commerce." Electronic Markets, Vol. 13, No. 3, pp. 196-209. 2003.

[18] Kotha, S., Rajgopal, S., Rindova, V. "Reputation building and performance: An empirical analysis or the top-50 pure internet firms", European Management Journal, Vol. 19, No. 6, pp. 571-586. 2001.

[19] Luo, W., Cook, D. "An empirical study of trust of third party rating services." Journal of Computer Information Systems, Vol. 48, No. 2, pp. 236-260. 2007.

[20] Van der Heijden, H., Verhagen, T., \& Creemers, M. Understanding online purchase intentions: contributions from technology and trust perspectives. European journal of information systems, European Journal of Information Systems, vol. 12, no. 1, pp. 41-48, 2003.

[21] Kesharwani, A., Bisht, S. S. "The impact of trust and perceived risk on Internet banking adoption in India: An extension of technology acceptance model." International Journal of Bank Marketing, Vol. 30, No. 4, pp. 303-322. 2012.

[22] Kim, D., Lee, K.-Y., Lee, D., Ferrin, D., Rao, R. "Trust, Risk and Benefit in Electronic Commerce: What are the Relationships? Americas conference on information systems (AMCIS) 2003 proceedings, FL, USA, pp. 168-174. 2003.

[23] Bitner, M. J. "The impact of physical surroundings on customers and employees", Journal of Marketing, Vol. 56, No. 2, pp. 57-71. 1992.

[24] Mwesigwa, R., Nkundabanyanga, S. K. "Consumer, attitude, trust, perceived risk and internet banking adoption in Uganda." Journal of Business and Economics, Vol. 2, No. 5, pp. 405-416. 2011.

[25] Namahoot, K., Laohavichien, T. "Assessing the intentions to use internet banking: The role of perceived risk and trust as mediating factors." International Journal of Bank Marketing, Vol. 36, No. 2, pp. 256-276, 2018.

[26] D. Zhu, G. S. O'Neal, Z. Lee and Y. Chen, "The effect of trust and perceived risk on consumers' online purchase intention," 2009 International Conference on Computational Science and Engineering, 2009, pp. 771-776, doi: 10.1109/CSE.2009.338.

[27] Kwok, M-L J., Wong, M-C M., Lau, M. C. "Examining how environmental concern affects purchase intention: Mediating role of perceived trust and moderating role of perceived risk." Contemporary Management Research, Vol. 11, No. 2, pp. 143-152. 2015.

[28] Mwesigwa, R. (2010). Consumers' Attitudes, Perceived Risk, Trust and Internet Banking Adoption in Uganda, Unpublished thesis in the MBA program at Makerere university.

[29] Man, Y. K. (2006). Factors Affecting Customer's Trust in Online Banking. Hong Kong: Hong Kong Baptist University

[30] Corritore, C. L., Marble, R. P., Wiedenbeck, S., Krancher, B., Chandran, A. (2009). "Measuring Online Trust of Websites: Credibility, Perceived Ease of Use, and Risk." Proceedings of the Eleventh Americas Conference on Information Systems, Omaha, NE, USA August 11-14, pp. 2419-2429.

[31] Sunm P. C., Luo, J. J., Liu, Y. L. (2010). "Perceived Risk and Trust in Online Group Buying Context." Paper presented in the 2010 International Conference on Information Management, Innovation Management and Industrial Engineering, IEEE computer society, pp. 660-663.

[32] Dillman, D. A. Mail and Internet Surveys: The Tailored Design Method, 2nd edition, NY, Imprint. 2000. 
[33] Podsakoff, P. M., MacKenzie, Lee, J.-L., Podsakoff, N. P. "Common method biases in behavioral research: A critical review of the literature and recommended remedies", Journal of Applied Psychology, Vol. 88, No. 5, pp. 879-903. 2003

[34] Chang, S.-J., Witteloostujin, A., Eden, L. "From the editors, Common method variance in international business research." Journal of International Business Studies, Vol. 41, pp. 178-184. 2010.

[35] Anderson, J., Gerbing, D. "Structural equation modeling in practice: A review and recommended two-step approach." Psychological Bulletin, Vol. 103, No. 3, pp. 411-423. 1988.

[36] Chang, H. H., Chen S. W. "The impact of online store environment cues on purchase intention: Trust and perceived risk as a mediator." Online information review, Vol. 36, No. 6, pp. 818-841. 2008.

[37] Hair, J. F. (2013). Essentials of Marketing Research, 3rd edition, NY, McGrawHill.

[38] Nunnally, J. C. (1978). Psychometric Theory, 2nd edition. NY, McGraw-Hill Book Company.

[39] Fornell, C., Larcker, D. "Evaluating structural equation models with unobservables and measurement error." Journal of Marketing Research, Vol. 18, No. 1, pp. 39-50. 1981.

[40] Mulylle, S., Moenaert, R., Despontin, M. "The conceptualization and empirical validation of web site user satisfaction." Information, \& Management, Vol. 41, pp. 543-560. 2004.

[41] Mou, J., Cohen, J. F. (2014). Trust, Risk, and Perceived Usefulness in Consumer Acceptance of Online Health Services. Paper presented in the 25th Australasian conference on information systems, Auckland, New Zealand, 2014.

[42] Akar, B., Nasir, V. A. (2014). "A critical review of online consumers' purchase intentions." Paper presented at the 2014 Advances in Business-related Scientific Research Conference (ABSRC 2014), Venice, Italy, pp. 26-28.

[43] Soltanpanah, H., Shafe'ei, R., Miranti, V. "A review of the literature of perceived risk and identifying its various facets in e-commerce by customers: Focusing on developing countries." South African Journal of Business Management, Vol. 6, No. 8, pp. 2888-2896. 2012.

[44] Comegys, C., Hannula, M., Vaisanen, J. "Effects of consumer trust and risk on online purchase decision-making: A comparison of Finnish and United states students." International Journal of Management, Vol. 26, No. 2, pp. 295-308. 2009.

[45] Sparks, B. A., Browning, V. "The impact of online reviews on hotel booking intentions and perception of trust." Tourism Management, Vol. 32, pp. 1310-1323. 2011.

[46] Ozturen, A. "Effects of electronic trust on purchase intentions in online social networks: The case of tripadvisor.com", Life Science Journal, Vol. 10, No. 2, pp. 2002-2010. 2013.

[47] Tangmanee, C., Rawsena, C. "Direct and indirect effects of perceived risk and website reputation on purchase intention." International Journal of Research in Business and Social Science, Vol. 5, No. 6, pp. 1-11. 2016.

[48] Kim, K. K., Prabhakar, B., Park, S. K. "Trust, perceived risk, and trusting behavior in Internet banking." Asia Pacific Journal of Information Systems, Vol. 19, No. 3, pp. 1-23. 2009. 
[49] Abarbanel, B., Bernhard, B., Singh, A. N., Lucas, A. "Impact of virtual atmospherics and functional qualities on the online gambler's experience", Bahaviour, \& Information Technology, Vol. 34, No. 10, pp. 1005-1021. 2015 
